\title{
Narrative and Literary Text as a Source of Self-knowledge and Self-cognition
}

\author{
Katarzyna Filutowska
}

The paper concerns the cognitive function of literature. I show that literary stories, because of their narrative and mimetic structure, enable us to identify with fictitious heroes, and thus become able to widen our cognitive as well as moral horizon, and to influence our own life-stories. In such a process, we receive the opportunity to re-tell and rethink our personal narration and in such a way learn who we really are and what it means to be ourselves. In order to demonstrate this, I refer to Martha Nussbaum's and Wayne C. Booth's ethical criticism on the one hand, and to Paul Ricoeur's, Alasdair MacIntyre's, Charles Taylor's, Marya Schechtman's and David DeGrazia's theory of narrative identity on the other. I argue that such a mutual exchange between the reader's identity and a fictional character is possible as both of them have a narrative structure and are sort of a story.

Key words: narrative, narrative identity, subjectivity, self, self-cognition, life-story, cognitive function of literature

In this paper, I would like to focus on the cognitive function of literature and show that literary stories, because of their narrative - that is to say, also mimetic - structure, enable us to identify with fictitious heroes, and thus become able to widen our cognitive as well as our moral horizon, and to influence our own life-stories. In such a process, we receive the opportunity to retell and re-think our personal narration and in such a way learn who we really are and what it means to be ourselves. In order to demonstrate this, I will refer to Martha Nussbaum's and Wayne C. Booth's ethical criticism on the one hand, and to Paul Ricoeur's, Alasdair MacIntyre's, Charles Taylor's, Marya Schechtman's and David DeGrazia's theory of narrative identity on the other. I would like to argue that such a mutual exchange between the reader's

KATARZYNA FILUTOWSKA, PhD, Institute of Philosophy, University of Warsaw; address for correspondence: Al. Jerozolimskie 117 m. 37, PL 02-017 Warszawa; e-mail: katarzyna.filutowska@gmail.com 
identity and a fictional character is possible as both of them have a narrative structure and are sort of a story.

\section{Cognitive Function of Literature}

Is fiction able to give us any cognitive profit at all? According to the positivist opinion, the answer has to be negative since the sentences of a novel are "if not quite self-referential, at least not interested in referring to anything real, to anything beyond itself" 1 . As such, they are neither true nor false, hence they are cognitively neutral and cannot be a source of knowledge. Some non-positivist theorists of literature share such a point of view on the status of literary statements even if they do not agree with the stronger thesis that literature does not have a cognitive value at all. In his analysis of the literary work of art, Roman Ingarden treats sentences of a novel as so-called quasi-judgements ${ }^{2}$. As Augustin Riska puts it, such a "declarative sentence" goes "beyond the purely intentional correlate, but it does not reach any objectively existing, real state of affairs; it only simulates such a state of affairs, pretends to constitute it"3.

In my paper, I argue that literary fictions are not deprived of cognitive value though the knowledge they provide does inform us about real states of affairs in such a way in which science or language in its "normal" use does it. What exactly does such literary knowledge consist of? According to John Gibson, literary narratives show us "human practice and circumstance". They do not make it "from an abstracted, external perspective" but do it in a metaphoric, figurative way, "from the "inside" of life, in its full dramatic form" This means that literature becomes a witness to the world, "engaged in a form of worldly investigation" 5 . Moreover, such literary cognition is never "value neutral" or "merely conceptual" as it has as a target "the values, cares

${ }^{1}$ J. Gibson, Literature and Knowledge, [in:] The Oxford Handbook of Philosophy and Literature, ed. R. Eldridge, Oxford University Press, New York 2009, p. 474.

${ }^{2}$ As for this problem see R. Ingarden, Das literarische Kunstwerk. Mit einem Anhang von den Funktionen der Sprache im Theaterschauspiel, Max Niemeyer Verlag, Tübingen 1965, p. 169-183.

${ }^{3}$ A. Riska, Language and Logic in the Work of Roman Ingarden, [in:] Ingardeniana. A Spectrum of Specialized Studies Establishing the Field of Research, ed. A.-T. Tymieniecka, D. Reidel Publishing Company, Dordrecht-Boston 1976, p. 205.

${ }^{4}$ J. Gibson, Literature and Knowledge, op. cit., p. 482. Such a literary reference is very close to the problem of a metaphorical reference which according to Ricoeur's views consists in "the eclipse of one referential mode as the condition for the emergence of another referential mode" as he puts it, "metaphor is that strategy of discourse by which language divests itself of its function of direct description in order to reach the mythic level where its function of discovery is set free" (P. Ricoeur, The Rule of Metaphor. Multi-disciplinary Studies of the Creation of Meaning in Language, Routledge \& Kegan Paul, London 1986, p. 239, 247).

5 J. Gibson, Literature and Knowledge, op. cit., p. 483. 
and concerns that define the character of our particularly human practices and experiences" 6 . Literary text always "establishes a type of dramatic relation between a knower and the world"7, hence it cannot merely know something but also take an attitude towards it, in short - put it in an order of values and goods.

Contrary to Gibson and Ingarden, I consider literature in the narrower context of narrative. In its great part, literature consists of telling stories. Every storyteller always takes a specifically human perspective as "storytelling is the most ubiquitous of human activities"8 - so popular, wide-spread and fundamental as language or culture itself. Narrative is, as Louis O. Mink puts it, "a primary cognitive instrument" and "an irreducible form of understanding" 9 which makes the flux of events, experiences and particular occurrences comprehensible by giving them a form of a story, that is to say, by transforming them into a single whole with a beginning-middle-end structure. As such, it remains "a rival to theoretical explanation or understanding" which would treat each of those occurrences "as nothing other than a replicable instance of systematically interconnected set of generalisations" 10 .

\section{Ricoeur and the Problem of So Called Threefold Mimesis}

There are various types of narratives. There are fictitious narratives as well as such which aspire to be true and which endeavour to present real events and people. As David Carr puts it, "traditional narrative histories claim to tell us what really happened. Fictional narratives portray events that of course by definition never happened, but they are often said to be true-tolife; that is, to tell us how certain events might have occurred if they had really happened" 11 .

Such a true story is constructed according to precisely the same rules which are used by creators of fabulous, untrue narrations. If this is a type of construction, is it able to present the world as it really is? Because of its mimetic form, story does not reflect a reality as such but depicts it according to certain poetics, from a certain point of view and so on. Carr writes that "real events simply do not hang together in a narrative way, and if we treat them

\footnotetext{
${ }^{6}$ Ibidem, p. 481.
}

7 Ibidem.

${ }^{8}$ L. O. Mink, Narrative Form as a Cognitive Instrument, [in:] The History and Narrative Reader, ed. G. Roberts, Routledge, London-New York 2001, p. 214.

${ }^{9}$ Ibidem, p. 213.

10 Ibidem.

11 D. Carr, Narrative and the Real World: an Argument for Continuity, "History and Theory" 1986, vol. 25, no. 2, p. 117. 
as if they did we are being untrue to life. Thus not merely for lack of evidence or of verisimilitude, but in virtue of its very form, any narrative account will present us with a distorted picture of events it relates"12. And as he clarifies further, referring to Roland Barthes' views, "in a story everything has its place in a structure while the extraneous has been eliminated"13. Every narrative has a beginning-middle-end structure which is essential to stories. However, it is "meaningless" in so-called real life which lasts all the time and in which no event is the first, the second, the third, or the last one.

In short, life is lived but stories are told or narrated. Stories imitate reality and are a type of mimetic art in the Aristotelian sense of this term. Such a possibility of considering narrations in the context of Aristotle's notion of mimesis is the basis of Ricoeur's analysis of narratives presented in his famous work Time and Narrative. According to his views, in order to tell a story, the narrator - likewise the author of a tragedy, for example Sophocles in $O e$ dipus at Colonus or in Antigone - first of all has to compose a plot, that is to say, to organise the events "into a system" 14 . As he puts it, in the same way Aristotle in his Poetics understands the notion of mimesis, imitation - as Ricoeur writes, "imitating or representing is a mimetic activity inasmuch as it produces something, namely, the organization of events by emplotment" 15 . Talking about things which have happened, like in a so-called true story or about, as Martha Nussbaum puts it, things such as might happen ${ }^{16}$, like every invented, fictitious story, the narrator imitates real events, giving them a form of narrative by composing a plot, by including them into a complete whole within the frames of which all of them are part of a common order, an element of a presented world, a given described reality.

Such a mimetic model pursues creating a coherent whole but it is not characterised by pure concordance. As Ricoeur claims, it is rather a kind of "discordant concordance" 17 without which the emplotment would be not possible at all. In a mimetic representation, such as a tragedy or a story, events do not follow each other in such a way that "one thing leads to another". As Ricoeur underlines, according to Aristotle's views we may distinguish in a tragedy various types of discordance which breaks logical or aes-

12 Ibidem.

13 Ibidem, p. 119.

${ }_{14}$ P. Ricoeur, Time and Narrative, vol. 1, The University of Chicago Press, Chicago-London 1984, p. 33.

15 Ibidem, p. 34.

${ }_{16}$ M. C. Nussbaum, Upheavals of Thought. The Intelligence of Emotions, Cambridge University Press, New York 2008, p. 238.

17 P. Ricoeur, Time and Narrative, vol. 1, op. cit., p. 42. 
thetical coherence, for example "fearful or pitiable incidents" which "constitute a major threat to the plot's coherence"18, surprises (events which occur unexpectedly), peripeteia, or a reversal which "turns good fortune into bad"19, or sometimes also bad into good and so on. Such a discordant concordance is crucial for the possibility of constructing a plot because without it the spectator could not fully identify with tragic heroes, feel pity and fear, and in consequence, experience catharsis, a purification of emotions and also a kind of a cognitive shock which leads to better understanding of who he or she is. As Ricoeur puts it, "the pitiable and the fearful are qualities closely tied to the most unexpected changes of fortune oriented toward unhappiness. It is these discordant incidents the plot tends to make necessary and probable. And in so doing, it purifies them, or, better, purges them" 20 .

Moreover, by means of the plot, our temporal experience is transformed into a story, which is an imitation of human actions and decisions taking place in time, that is to say, succeeding one after another in time. In other words, the plot and the emplotment play "the mediating role" between time and the narrative or, as Ricoeur writes, "between a stage of practical experience that precedes it and a stage that succeeds it" 21 . According to his interpretation, this process of transformation which he identifies with a so-called threefold mimesis has three main levels - mimesis I, mimesis II and mimesis III. As Katrina McNeely Farren puts it, "The first level of mimesis, or prefiguration, refers to our intuitive preunderstanding of what is taking place in mimesis. In other words, there are some basic understandings that the reader must already have [...] if she is going to comprehend what is happening in the narrative"22. Such an intuitive preunderstanding which is anchored in "the composition of the plot" concerns three main aspects of the world of action, namely "its meaningful structures, its symbolic resources, and its temporal character"23. First of all, in order to grasp the sense of a story, the reader or listener has to know the structure of the action - be able to identify the agent (the "who?" of the action), to recognise his or her motives (the "why?" of the action), then to make a connection between "who?" and "why?", and so on.

18 Ibidem, p. 43.

19 Ibidem.

20 Ibidem, p. 44.

21 Ibidem, p. 53.

22 K. McNeely Farren, Narrative Identity in Paul Ricoeur and Luce Irigaray: The Circularity Between Self and Other, Michigan Technological University 2010, http://gradworks.umi.com/3403377.pdf [access: 1.1.2016], p. 88.

23 P. Ricoeur, Time and Narrative, vol. 1, op. cit., p. 54. 
Secondly, he must be aware of various "signs, rules and norms" 24 used to articulate our action within the frames of a given culture or society, to understand the symbolical (cultural) mediation of a narration. For example, the reader or the spectator of Sophocles' Antigone has to know some ritual and cultural circumstances related to the problem of a burial in an ancient Greece in order to fully understand Antigone's attitude and actions - her obstinacy concerning the necessity of burying her brother Polynices in spite of Creon's prohibition. Thirdly, he has to be able to "recognise in action temporal structures that call for narration"25, expressed for example in such adverbs as "then, after, later, earlier, since, until, so long as, during, all the while that, now that, etc." 26 .

Mimesis II is responsible for the operation of emplotment. According to Ricoeur, it "opens the kingdom of as if" 27 and "draws a configuration out of simple succession" 28 , bringing together "factors as heterogeneous as agents, goals, means, interactions, circumstances, unexpected results" 29 . In other words, this is a poetic, creative act in the proper sense of this term, which finally leads to creating the narrative as a complete whole, an independent story with a precisely determined beginning, middle and end. According to Ricoeur's views, “This act [...] reveals itself to the listener or the reader in the story's capacity to be followed" 30 . What does such a "story's capacity to be followed" consist of? As Ricoeur puts it, "to follow a story is to move forward in the midst of contingencies and peripeteia under the guidance of an expectation that finds its fulfilment in the conclusion" 31 . In short, such a capacity is related to the internal logic of events which in spite of all reversals, discordances and unexpected turns of an action makes them understandable and necessary parts of one whole and which culminates in an ending. Ricoeur underlines that an ending "is not logically implied by some previous premises. It gives the story an "end point" which, in turn, furnishes the point of view from which the story can be perceived as forming a whole. To understand the story is to understand how and why the successive episodes led to this conclusion, which, far from being foreseeable, must finally be acceptable, as congruent with the episodes brought together by the story" 32 .

\footnotetext{
24 Ibidem, p. 57.

25 Ibidem, p. 59.

26 Ibidem, p. 62.

27 Ibidem, p. 64.

28 Ibidem, p. 65.

${ }^{29}$ Ibidem.

30 Ibidem, p. 66.

31 Ibidem.

32 Ibidem, p. 67.
} 
Lastly, mimesis III concerns the process of refiguration. It "marks the intersection of the world of the text and the world of the hearer or reader; the intersection, therefore, of the world configured by the poem and the world wherein real action occurs and unfolds its specific temporality" 33 . This level refers to the act of reading, to the problem of reception and the way in which the reader or listener actualises the world depicted and told by the author, recreating by this means the text which only in such a mutual exchange becomes a complete story or - in the case of fictive, literary narratives - also a work of art. In other words, such an act of reading is a fulfilment of the act of configuration which was crucial for the second stage of mimesis (to mimesis II) and is equal to the author's creative activity. In this third phase, the writer's or storyteller's vision of some reality he or she wants to describe is transmitted through the medium of the written or told story to the receiver but in such a way that he must rebuild it in his own imagination, repeating to some extent the author's act of creation. Moreover - as Ricoeur underlinessuch a text is "a set of instructions that [...] the reading public executes in a passive or a creative way" 34 , showing that every act of reading is individual and every reader may beget his own novel or a story which in some cases may even vastly differ from the author's original idea. The narrative (the process of the emplotment) does not exist and could not be followed without this third level which is its necessary completion.

Summing up the story is tied to the real world in many different ways. First of all, it is derived from reality in such a way that in order to tell or to understand a narration, the receiver as well as the teller must have an intuitive preunderstanding of the structure of an action as such because the narrative imitates human actions and does it even in such cases in which it depicts worlds which are totally imagined and fictive and have nothing to do with the circumstances of our everyday life (it often occurs in fables or sci-fi literature). Moreover, no story exists in a total vacuum. As Martin Kreiswirth puts it, "the narrative and the fictive are categories that stem not from textual objects but from the competencies and expectations of audiences"35. In consequence, in order "to confer story status on a given phenomenon" the interpreter cannot limit himself only to the text and its "intrinsic elements" but should know above all "extrinsic learned behaviours, tacit rules and explanatory stances" 36 which function in a given culture or society as a part of its

33 Ibidem, p. 71.

${ }^{34}$ Ibidem, p. 77.

${ }^{35}$ Routledge Encyclopedia of Narrative Theory, ed. D. Herman, M. Jahn, M.-L. Ryan, Routledge. Taylor\&Francis Group, London-New York 2010, p. 381.

36 Ibidem, p. 381. 
symbolical frames without which, according to Ricoeur's conception of mimesis I, we would not be able to articulate our actions at all - (that is to say, also as an element of the above-mentioned intuitive preunderstanding). Stories come into being in given culture or society and become a part of it, function within its limits, are told, retold, repeated, changed, mixed with other stories, traditions, literary works with which they discuss and are in a permanent exchange and so on, in short - they exist as invented and created by people for the audience, that is to say, for the other people in human, cultural environment. As Ricoeur claims, in the process of so-called threefold mimesis, one may observe how the stories in a given cultural, language reality, gain autonomy as complete wholes, sometimes works of art, and finally come back to the real world when the receiver actualises them in the act of reading and in consequence they have a chance to influence and even change reality. In other words, this process which depicts their relation to the real world and within the frames of which they exist and function has a typically circular structure and this is the reason why Ricoeur calls it "the Circle of Mimesis".

\section{Narratives and Emotions - Martha Nussbaum's Theory}

Why and in which way can stories influence the receiver's world? As Ralf Schneider writes, "understanding narrative [...] is never purely cognitive. It is one of the major attractions of narratives, whether presented in novels, plays, or films, that they elicit emotional responses in their audiences" ${ }^{37}$. Or, according to Martha Nussbaum, "our [...] relation to the books we love is already messy, complex, erotic" 38 . Narratives - literary as well as "authentic", fictitious as well as so-called "true relations of what has really happened" as a kind of mimetic representation of the imitation of real actions undertaken by real agents - belong to the same genre as the Greek tragedy described by Aristotle in his Poetics and as such they affect the receiver on the same rule - evoking feelings, such as for example pity and fear.

Why do narratives elicit emotions? They can do it because although they frequently describe entirely or at least to some extent fictitious situations, circumstances, people etc., they are not completely deprived of a connection with the way in which things, in fact, happen in a so-called real world. As a typical mimetic representation, they imitate real actions and choices of real people, thus presenting us plausible, alternative versions of our own actions

37 Ibidem, p. 136.

38 M. C. Nussbaum, Love's Knowledge: Essays on Philosophy and Literature, Oxford University Press, New York-Oxford 1992, p. 29. 
and decisions. In other words, they in some way concern our own possibilities so we can identify with their heroes, have compassion with them because we know that although the situation depicted by the author is not real but invented by him or her "we are also aware that these are possibilities for all human beings, hence the story of our own situation in the world"39. Martha Nussbaum continues by saying that "literary works [...] show us general plausible patterns of action, "things such as might happen" in human life. [...] If the work were not held to life in this way, by threads of plausibility, it could not engross us emotionally as it does. We see this when we read a work that is unsuccessful: we don't have real emotions when we haven't managed to care about the story as the sort of things that might happen" 40 .

In short, narratives evoke emotions because they are tied to the experienced world of the receiver (reader or listener). Moreover, without such an ability to experience narrations and identify with their heroes, we would not be able to understand them or we would understand them only superficially. Aristotle's theory of catharsis shows it very convincingly - the tragedy elicits deep feelings, such as pity and fear, without which the spectator cannot at all grasp its sense and the truth it is going to communicate. Such deep experiencing and understanding is possible because emotions are not "unthinking energies that simply push the person around, without being hooked up to the ways in which she perceives or thinks about the world" 41 but they themselves are a form of a thought and, as Martha Nussbaum puts it, have a narrative and in consequence have, to some extent, a rational structure.

Why does such an opinion seem to be right? Martha Nussbaum claims that emotions are intentional, concern an object and as such require representation and narration. We could feel compassion because we are able to imagine the person who suffers and to recreate the whole story of his or her pain - its reasons, character, course, people who hurt him or her etc. In such a way, our imagination helps us "bring a distant individual into the sphere of our goals and projects, humanising the person and creating the possibility of attachment" 42 . Nussbaum refers to Proust's point of view, according to whom "certain truths about the human emotions can be best conveyed, in verbal or textual form, only by a narrative work of art"43. In Marcel's novel In search of lost time, the Narrator tells the story of his life and how he became a writer. In his memory, emotions and feelings which remind him of the years when

\footnotetext{
${ }^{39}$ Eadem, Upheavals of Thought..., op. cit., p. 245.

40 Ibidem, p. 243, 245.

${ }^{41}$ Ibidem, p. 24-25.

42 Ibidem, p. 66.

43 Ibidem, p. 236.
} 
he was young are inseparably intertwined with various stories concerning people, places and things such as famous madeleine cake through the medium of which he remembered those bygone times and now talks about them trying to understand who he is. As Nussbaum puts it, emotions always "have a history" ${ }^{\prime 4}$. They do not exist without a narration through the medium of which a person who experiences given feeling tries to express his or her internal sensations and by this way understands what they exactly mean to him or her.

Summing up, stories can influence the receiver because they elicit emotions - and they can do it because they are able to "create surprise, uncertainty, as suspense as to what will happen or [...] how things happen"45, in a word - to evoke interest which is an effect of the fact that "the reader, viewer or listener relates emotionally to the agents in a fictional world, is interested in their fate, and prefers certain outcomes of stories to other" 46 . In such a way, the receiver can identify with his or her favourite characters, to feel for them and their experiences and sufferings because he or she "has possibilities and vulnerabilities similar to those of the sufferer" 47 and more generally because of the fact that the narration presents us our own alternative possibilities, "things such as might happen", choices we might make in circumstances similar to those in which are heroes of a given story which is being told and so on.

\section{Narratives and Self-cognition}

Such a possibility of identifying with fictive characters is an effect of the fact that a difference between the narration and something we call "our real world" is sometimes hard to grasp as the story belongs to reality, is derived from it, and ultimately always comes back to it. Moreover, it has significant consequences for our ability to value and make moral choices. As Paul Ricoeur puts it, although "in the unreal sphere of fiction" in which we are forced to "suspend all real moral judgement at the same time that we suspend action itself", it does not mean that we do not evaluate and value at all. Such invented though plausible worlds in which we follow imaginary actions, decisions and adventures of fictitious characters are - on the contrary - an excellent occasion "of exploring new ways of evaluating": "The thought experi-

\footnotetext{
44 Ibidem, p. 175.

${ }^{45}$ Routledge Encyclopedia of Narrative Theory, op. cit. p. 136.

46 Ibidem.

47 M. C. Nussbaum, Upheavals of Thought..., op. cit., p. 316.
} 
ments we conduct in the great laboratory of the imaginary are also explorations in the realm of good and evil. Moral judgement has not been abolished; it is rather itself subjected to the imaginative variations proper to fiction" 48 .

Although literary narratives are not true but invented, they are nevertheless to some extent possible because - at least as for their structure - they imitate real actions of real people undertaken in the real world. Here, in the realm of as if, we can observe how ethics connect with aesthetics, how ethical questions concerning actions, choices, intentions and motivations overlap with those which are related to the world of literary fiction and mimetic imitation. Identifying with fictitious heroes, we gain an opportunity of exploring such ways of thinking, valuing and experiencing which are not available in real life. This way, we can imaginatively explore our own internal boundaries and in consequence, better understand what we might do in various situations and circumstances, which are our own possibilities, who we really are.

Such a possibility of a mutual influence between literature on the one hand and our real life on the other is an effect of the fact that according to the conception of narrative identity our self also has a narrative structure. We like Marcel, the Narrator of Proust's In search of lost time - are also heroes of our own autobiographical story, characters in search of a main, central good or value which will make our life understandable, full of sense, complete, whole. As Charles Taylor puts it, "in order to have an identity, we need an orientation to the good" 49 . Without such an orientation, such knowledge where I am coming from, where I am going to, what kind of good I want to fulfil in my life and which values are the most important for me, I will not know who I am and I will not be able to be myself. Such an endeavour, after making our own vision of good real - such as for example art for an artist, God for a believer, revolution for a Marxist, truth or wisdom for a philosopher or a scientist, and so on - makes us who we are because it makes our existence significant, thus giving us a chance to tell it as a coherent, meaningful story. According to such a conception, our identity should be considered as "a concept of a self whose unity resides in the unity of a narrative which links birth to life to death as narrative beginning to middle to end. [...] we understand our own lives in terms of the narratives that we live out"50. Ricoeur puts it even more explicitly in the Conclusion of the third part of Time and Narrative, in which he writes the following words: "To answer the question

48 P. Ricoeur, Oneself as Another, The University of Chicago Press, Chicago-London 1992, p. 164. As for this problem see also for example P. Ricoeur, Time and Narrative, vol. 1, op. cit., p. 59.

${ }^{49} \mathrm{Ch}$. Taylor, Sources of the Self. The Making of the Modern Identity, Harvard University Press, Cambridge-Oakleigh 1992, p. 47.

50 A. MacIntyre, After Virtue. A Study in Moral Theory, University of Notre Dame Press, Notre Dame, Indiana 1984, p. 205, 212. 
"Who?" [...] is to tell the story of a life. [...] And the identity of this "who" therefore itself must be a narrative identity" 51 .

In consequence, "the identity of a person is the identity of a character": "we make sense of our own and of others' biographies the same way we understand stories: by following a plot and the protagonist featured in it"52. Reading about fictitious choices of literary characters, we may have compassion and even identify with them because we also think about our own, real life within the frames of a story, that is to say, in narrative categories - we also suffer and look for luck, we also have to fight with reverses of fortune, to overcome difficulties and obstacles, sometimes make unobvious choices, and so on. Identifying with fictitious heroes, imagining what kind of choice I would make I were in their place, in short - confronting my "normal", defined by certain social, cultural norm and conformable to them self with something sometimes completely different, I extend my own as well as, more generally, also social narration, part of which is my personal life story, including into it imaginary ideas invented by the author of given story. In this way, I have an opportunity to rethink and reconstruct it, to write or tell it anew - and by this means, I get a chance to discover and to understand who I really am or could be.

Why is such a literary experiment with values not only a play but a source of true self-knowledge? In the case of a narrative identity, I am the only person who can be the narrator in my own life story and nobody can replace me. As David DeGrazia puts it, when the problem "who am I?" is at stake, "only an answer that favours the first-person standpoint does justice to such a first-person question"53. Only such a life story in which I myself am a narrator is credible because a first-person perspective is the only proof that a given autobiography reflects my own point of view, my true desires, wishes, aims an so on. In consequence, when I read a story and I do it in a really, as

51 P. Ricoeur, Time and Narrative, vol. 3, The University of Chicago Press, Chicago-London 1988, p. 246.

52 Routledge Encyclopedia of Narrative Theory, op. cit. p. 231.

53 D. DeGrazia, Human Identity and Bioethics, Cambridge University Press, Cambridge-New York-Melbourne-Madrid-Cape Town-Singapore-Sao Paulo 2005, p. 84. Marya Schechtman also underlines an importance of the first-person perspective in the case of a personal life-story - as for this problem see for example: "An identity in the sense of the characterization question, is not [...] something that individual has whether she knows it or not, but something that she has because she acknowledges her personhood and appropriates certain actions and experiences as her own" (M. Schechtman, The Constitution of Selves, Cornell University Press, New York-London 2007, p. 95). 
Wayne C. Booth puts it, aesthetic way ${ }^{54}$, which lets me identify my own personal narrative with its heroes, my identity, my genuine self is always at stake just because I am a person who follows a given story, I see from my own point of view which is not fictive but real.

In this third level of mimesis - in the phase of refiguration - when the narrative proposed by given text is confronted with ours - the reader's - expectations, endeavours and desires which shape our own personal narratives we "acquire, from the stories we are told, a desire to become a different kind of desirer"55. In consequence, in such a process, our self, that is to say, our life story is to some extent re-told, re-read and re-written and we have the opportunity to get to know ourselves better, to discover such aspects of our personality which are not obvious, which might be deeply hidden although in spite of that they may remain to some extent core to our true self, in a word - to enlarge life's possibilities, to better know who we really are or might be.

Why do we need literature to achieve such an aim? In so-called real life, we are always concrete, definite persons living in a given time and in a given society in which we usually play one or more - but not an infinite number of - roles. In such a world, the boundaries of our identity are more or less precisely defined. We do not know ourselves because we treat our "real" world as obvious, certain, and the only possible one, and we do not have the opportunity to explore how we may react or act in an alternative world or at least in an alternative state of affairs. In consequence, such alternative ways of living cannot become a part of our personal life story as we cannot experience them and sometimes even think that they may occur.

In other words, we need literature and narrative stories because, as Nussbaum puts it, "we have never lived enough": "Our experience is, without fiction, too confined and too parochial. Literature extends it, making us reflect and feel about what might otherwise be too distant for feeling"56. And, as she writes earlier, the literary text is in such a way 'an 'optical instrument' through which the reader becomes a reader of his or her own heart" 57 . Literature gives us such a possibility of conducting an experiment with values, of experiencing something completely different, becoming a source of a transgression and widening our moral as well as cognitive horizon. According to Liesbeth Korthals Altes, who refers to the problem of so-called ethical critics,

54 W. C. Booth, The Company We Keep. An Ethics of Fiction, University of California Press, Berkeley-Los Angeles-London 1988, p. 281.

55 Ibidem, p. 272.

56 M. C. Nussbaum, Love`s Knowledge..., op. cit., p. 47.

57 Ibidem. 
"it provides a kind of experiential learning, suggests alternatives for "how to live the good life", and exercises moral awareness and flexibility. [...] Thus the novel could become a laboratory for testing social norms and values. In practice, while novelists and readers discover the thrills of transgression, the horizon of morality remains very present, and much fiction criticism and reception still tends to be moralistic"58.

Such narrative, literary experiments with values do not directly change our "real" world but they are not completely without influence on our lifenarratives. As representants of ethical critics claim, literature answers the question of how to live a good life. In such a way, it may influence our real world and even change it. Such a point of view is very close to Ricoeur's conception of mimesis. In the third, last phase of the act of reading, the world of a text intersects with the world of the reader and only in such a process the story which is being told by the writer has a chance to be actualised, to become a complete whole and in consequence, to shape the reader's personal narrative becoming, as Booth puts it, "the very source of our being" 59 and make us who we are. It may encourage to adopt a given lifestyle, call attention to certain problems previously treated as marginal, widen and enlarge sensitivity and moral awareness to certain questions, show the ultimate consequences of some political or social assumptions, in short - show what is important or, as Nussbaum puts it, "what matters" 60 .

\section{Conclusions}

To sum up, literary, narrative fictions have their origins precisely in the same world in which "real" events and actions they imitate occur and talk about our own possibilities, about alternative, possible worlds, alternative states of affairs which are not true but in spite of that might be true. Although literature presents fictitious, untrue stories, it may influence the real world and shape our identity (ourselves). It is related to the fact that in terms of its structure, every narrative - literary as well as so-called true - has a mimetic character and imitates real actions of real people and this is the reason why it may influence its readers.

We may experience fictitious stories and identify with their heroes and, on the other hand, they may change and shape us because our own self also has a narrative form - namely it is a kind of life story in which we our-

\footnotetext{
${ }^{58}$ Routledge Encyclopedia of Narrative Theory, op. cit. p. 142.

59 W. C. Booth, The Company We Keep..., op. cit., p. 265.

60 M. C. Nussbaum, Love`s Knowledge..., op. cit., p. 26.
} 
selves are narrators, storytellers. Reading about fictitious choices and actions of invented characters we may re-write and re-tell our own self, extend and change our life story and in such a way better understand ourselves, ask once again who we really are. This is maybe the greatest stake in this literary but at the same time quite serious game which is never purely and totally fictitious even if it pretends to be.

\section{References}

Booth W. C., The Company We Keep. An Ethics of Fiction, University of California Press, Berkeley-Los Angeles-London 1988.

Carr D., Narrative and the Real World: an Argument for Continuity, "History and Theory", 1986, vol. 25, no. 2, p. 117-131.

DeGrazia D., Human Identity and Bioethics, Cambridge University Press, Cambridge-New York-Melbourne-Madrid-Cape Town-Singapore-Sao Paulo 2005.

Gibson J., Literature and Knowledge, [in:] The Oxford Handbook of Philosophy and Literature, ed. Richard Eldridge, Oxford University Press, New York 2009, p. 467-485.

Ingarden R., Das literarische Kunstwerk. Mit einem Anhang von den Funktionen der Sprache im Theaterschauspiel, Max Niemeyer Verlag, Tübingen 1965.

MacIntyre A., After Virtue. A Study in Moral Theory, University of Notre Dame Press, Notre Dame, Indiana 1984.

McNeely Farren K., Narrative Identity in Paul Ricoeur and Luce Irigaray: The Circularity Between Self and Other, Michigan Technological University 2010, http://gradworks.umi.com/3403377.pdf [access: 1.1.2016], p. 88.

Mink L. O., Narrative Form as a Cognitive Instrument, [in:] The History and Narrative Reader, ed. Geoffrey Roberts, Routledge, London-New York 2001, p. 211-220.

Nussbaum M. C., Upheavals of Thought. The Intelligence of Emotions, Cambridge University Press, New York 2008.

Nussbaum M. C., Love's Knowledge: Essays on Philosophy and Literature, Oxford University Press, New York-Oxford 1992.

Ricoeur P., Oneself as Another, The University of Chicago Press, Chicago-London 1992.

Ricoeur P., The Rule of Metaphor. Multi-disciplinary Studies of the Creation of Meaning in Language, Routledge \& Kegan Paul, London 1986.

Ricoeur P., Time and Narrative, vol. 1, The University of Chicago Press, Chicago-London 1984.

Ricoeur P., Time and Narrative, vol. 3, The University of Chicago Press, Chicago-London 1988.

Riska A., Language and Logic in the Work of Roman Ingarden, [in:] Ingardeniana. A Spectrum of Specialized Studies Establishing the Field of Research, ed. A.-T. Tymieniecka, D. Reidel Publishing Company, Dordrecht-Boston 1976, p. 187-218.

Routledge Encyclopedia of Narrative Theory, ed. D. Herman, M. Jahn, M.-L. Ryan, Routledge. Taylor\&Francis Group, London-New York 2010.

Schechtman M., The Constitution of Selves, Cornell University Press, New York-London 2007. 
Taylor Ch., Sources of the Self. The Making of the Modern Identity, Harvard University Press, Cambridge-Oakleigh 1992.

\section{Streszczenie}

\section{Narracja i tekst literacki jako źródło samowiedzy i samopoznania}

Artykuł dotyczy poznawczej funkcji literatury. Pokazuję, że ze względu na swoją narracyjną, mimetyczną strukturę literackie narracje umożliwiają nam utożsamianie się z fikcyjnymi bohaterami, a w ten sposób poszerzają nasz horyzont poznawczy i wpływają na nasze własne opowieści biograficzne. W tym procesie zyskujemy możliwość przemyślenia i opowiedzenia na nowo naszych autonarracji i dowiedzenia się, kim naprawdę jesteśmy i co to znaczy być sobą. Aby to udowodnić, odwołuję się do krytyki etycznej Marty Nussbaum i Wayne`a C. Bootha z jednej strony oraz do koncepcji tożsamości narracyjnej Paula Ricoeura, Alasdair`a MacIntyre`a, Charlesa Taylora, Maryi Schechtman i Davida De Grazii z drugiej. Argumentuję, że taka wzajemna wymiana pomiędzy tożsamością czytelnika i tożsamością fikcyjnej postaci jest możliwa, ponieważ obydwie one mają charakter narracyjny.

Słowa kluczowe: narracja, tożsamość narracyjna, podmiotowość, ja, samowiedza, life-story, poznawcza funkcja literatury

\section{Zusammenfassung}

\section{Narration und literarischer Text als Quelle des Selbstwissens und der Selbsterkenntnis}

Der Artikel betrifft die Erkenntnisfunktion der Literatur. Es wird gezeigt, dass uns die literarischen Narrationen aufgrund ihrer erzählerischen mimetischen Funktion ermöglichen, uns mit fiktionalen Helden zu identifizieren. Auf diese Weise erweitern sie unseren Erkenntnishorizont und beeinflussen unsere eigenen biografischen Erzählungen. In diesem Prozess gewinnen wir die Möglichkeit, über unsere Autonarrationen nachzudenken, sie aufs Neue zu erzählen und uns zu erkundigen, wer wir wirklich sind und was unser Selbst ausmacht. Um den Beweis dafür zu erbringen, beziehe ich mich einerseits auf die ethische Kritik von Marta Nussbaum und Wayne C. Booth, andererseits auf den Entwurf der narrativen Identität von Paul Ricoeur, Alasdair MacIntyre, Charles Taylor, Marya Schlechtman und David de Grazia. Ich argumentiere damit, dass ein solcher Austausch zwischen der Identität des Lesers und der Identität der fiktionalen Gestalt möglich ist, weil beide einen narrativen Charakter haben.

Schlüsselworte: Narration, narrative Identität, Subjektivität, Ich, Selbstwissen, lifestory, Erkenntnisfunktion der Literatur 
Pobrane z czasopisma http://kulturaiwartosci.journals.umcs.pl

Data: 26/04/2023 11:30:12

Katarzyna Filutowska, Narrative and Literary Text...

Informacja o autorze:

KATARZYNA FILUTOWSKA, doktor, Instytut Filozofii UW, adres do korespondencji: Aleje Jerozolimskie 117 m. 37, 02-017 Warszawa, e-mail: katarzyna.filutowska@gmail.com

\section{(cc) EY-NC-ND}

